\begin{tabular}{c|c|c}
\hline \hline Vol. 273: 89-96, 2004 & MARINE ECOLOGY PROGRESS SERIES \\
Mar Ecol Prog Ser & Published June 8 \\
\hline \hline
\end{tabular}

\title{
Coral-associated Archaea
}

\author{
Linda Wegley ${ }^{1}$, Yanan $\mathrm{Yu}^{1}{ }^{1}$, Mya Breitbart ${ }^{1}$, Veronica Casas $^{1}$, David I. Kline ${ }^{1,2,3}$, \\ Forest Rohwer ${ }^{1,4, *}$ \\ ${ }^{1}$ Department of Biology, LS316, San Diego State University, 5500 Campanile Dr, San Diego, California 92182-4614, USA \\ ${ }^{2}$ University of California, San Diego, Scripps Institution of Oceanography, La Jolla, California 92093-0202, USA \\ ${ }^{3}$ Smithsonian Tropical Research Institute, Apartado 2072, Balboa, Panama \\ ${ }^{4}$ Center for Microbial Sciences, San Diego State University, 5500 Campanile Dr, San Diego, California 92182, USA
}

\begin{abstract}
The coral holobiont includes the coral, zooxanthellae, fungi, endolithic algae, and $>30$ species of Bacteria. Using culture-independent techniques, we now show that Archaea are also abundant and widespread on corals. Sequence analyses of Archaea on 3 species of Caribbean corals revealed that coral-associated Archaea are novel, diverse, and include representatives from both the Crenarchaeota and Euryarchaeota. Unlike zooxanthellae and Bacteria, the Archaea do not appear to form species-specific associations with reef-building corals. Fluorescent in situ hybridizations with peptide nucleic acid (PNA) probes showed that Archaea were present at $>10^{7}$ cells $\mathrm{cm}^{-2}$ on Porites astreoides, comprising nearly half of the prokaryotic community. This study and one by Kellogg (Mar Ecol Prog Ser 273:81-88) show that Archaea are abundant, diverse, and potentially important components of the coral holobiont.
\end{abstract}

KEY WORDS: Coral · Archaea · 16S rDNA · Fluorescent in situ hybridization · FISH · Peptide nucleic acid probe $\cdot$ PNA

Resale or republication not permitted without written consent of the publisher

\section{INTRODUCTION}

Archaea are prokaryotes representing a third Domain of life and are genetically distinct from Bacteria and Eukaryotes (Woese et al. 1990). Three kingdoms have been assigned to Archaea: the Crenarchaeota, the Euryarchaeaota (Woese et al. 1990), and the Korarchaeota (Brans et al. 1996). Initially Archaea were believed to be limited to anaerobic, hyperthermal, and highly saline habitats (DeLong 1998). However, culture-independent techniques based on $16 \mathrm{~S}$ rDNA analyses have shown that Archaea are common in marine and other environments (DeLong 1992, Fuhrman et al. 1992, 1993, 1994, DeLong et al. 1994, Fuhrman \& Davis 1997, Massana et al. 1997, 2000, Murray et al. 1998, 1999, Karner et al. 2001). Archaea have been shown to reside in coastal and offshore temperate waters worldwide (DeLong 1992, Fuhrman et al. 1992, 1993, Massana et al. 1997), Antarctic surface water (DeLong et al. 1994, Murray et al. 1998, 1999), and circumpolar deep ocean waters (DeLong et al.
1994, Murray et al. 1998, 1999). Pelagic Archaea may numerically dominate the marine plankton inhabiting meso- and bathypelagic zones of the ocean (Fuhrman et al. 1993, 1994, Karner et al. 2001). Marine Archaea are represented by 3 groups: Marine Group I (Crenarchaeotes) and Marine Group II (Euryarchaeotes; DeLong 1992), as well as Marine Group III, Euryarchaeotes, representing a third lineage of marine Archaea found in deep sea samples collected from both the Atlantic and Pacific Oceans (Fuhrman \& Davis 1997).

Archaea form symbiotic relationships with macroorganisms, the best studied being euryarchaeal methanogens that live symbiotically in ruminants (Smith \& Hungate 1958). The first characterization of crenarchaeal symbiosis was described when the Marine Group I related archaeon Cenarchaeum symbiosum was shown to have a highly specific relationship over space and time with the marine sponge Axinella mexicana (Preston et al. 1996). Subsequent studies revealed that other closely related Crenar- 
chaeotes were associated with 3 other Axinella sponges (Margot et al. 2001). Each species of Axinella was inhabited by a specific archaeal phylotype, suggesting a consistent association of Crenarchaeotes with Axinella sponges (Margot et al. 2001). It has also been shown that both Euryarchaeotes and Crenarchaeotes are associated with specific tissues on the Great Barrier Reef sponge Rhopaloeides odorabile, indicating the possibility of a beneficial relationship between host and microbiota (Webster et al. 2001).

Corals form symbioses with algae and prokaryotes. They live symbiotically with zooxanthellae (unicellular dinoflagellates) and display patterns of specific associations that are often related to depth (Rowan \& Knowlton 1995a,b, Rowan et al. 1997, Rowan 1998). On the Great Barrier Reef, for example, numerous species of coral host different taxa of algal symbionts in shallow versus deep water (Baker 1997). Symbiotic relationships and specific associations between corals and their bacterial communities have also been described (Peters 1984, Shashar et al. 1994, Ritchie \& Smith 1995, 1997, Santavy 1995, Rohwer et al. 2001, 2002). Different species of nitrogen-fixing bacteria are associated with certain corals and or their skeletons (Williams et al. 1987, Shashar et al. 1994, Kuhl et al. 1995). Santavy (1995) demonstrated that a bacterial species forms ovoids inside Porites astreoides and appears to be a normal component of the coral's life. More recently, a $\gamma$-proteobacterium designated PA1 was detected on Porites spp. in both Panama and Bermuda, suggesting that coral-bacterial associations are maintained across distant locations (Rohwer et al. 2002). Also, Montastrea franksi appears to harbor a specific $\alpha$-proteobacteria (Rohwer et al. 2001). Corals are also associated non-specifically with other organisms, including the protist Apicomlexia (Toller et al. 2002), several types of fungi (Le Campion-Alsumard et al. 1995a,b, Bentis et al. 2000), and endolithic algae (Odum \& Odum 1955, Shashar et al. 1997). Here we show that Archaea are diverse and abundant on reef building corals. A similar study by Kellogg (2004, this volume) reaches similar conclusions based on different coral species from the U.S. Virgin Islands.

\section{MATERIALS AND METHODS}

Sample collections and DNA preparations. Coral samples were collected at Whale Bone Bay, Bermuda (August 1999) and Bocas del Toro, Panama (April 1999 and June 2000). A punch and hammer was used to remove $1.3 \mathrm{~cm}$ diameter cores from Colpophyllia natans, Porites furcata, Diploria strigosa, Montastrea franksi, and Porites astreoides. The latter 3 species were sampled in both Bermuda and Panama, while $C$. natans and $P$. furcata were only sampled in Panama. Acropora cervicornis and Acropora prolifera samples were collected using bone clippers from La Parguerra, Puerto Rico (January 2002). After harvesting, the samples were immediately placed in a Ziploc bag underwater. At the surface each sample was washed with $0.2 \mu \mathrm{m}$ filtered and autoclaved seawater to remove any loosely associated microbes, placed on ice, returned to the lab, and frozen. Samples of $P$. astreoides and D. strigosa from Panama were also placed in $2 \%$ paraformaldehyde and stored at $4^{\circ} \mathrm{C}$ for the fluorescent in situ hybridizations (FISH).

For the DNA extraction, each frozen coral sample was airbrushed $(<2.7$ bar) with $10 \times$ TE [100 mM Tris (hydroxymethyl)aminomethane hydrochloride ( $\mathrm{pH} 8.0)$ / $10 \mathrm{mM}$ ethylenediaminetetraacetic acid (EDTA)] to remove the tissue and associated microbes. Two $\mathrm{ml}$ of the coral tissue/TE slurry was pelleted for $30 \mathrm{~min}$ at $10000 \times g$ at $4^{\circ} \mathrm{C}$. Total DNA was extracted from the pellet using the Ultra Clean Soil DNA Kit (Mo Bio).

To check the DNA, partial bacterial 16S rDNA were PCR amplified using the Bacteria-specific 27F primer (5'-AGAGTTTGATCMTGGCTCAG-3') and the universal 1492R primer (5'-TACGGYTACCTTGTTACGACTT-3'; Amann, et al. 1995). The PCR reaction contained 1× REDTaq Buffer, 1 U REDTaq (Sigma), $200 \mu \mathrm{M}$ each dNTP, $1 \mu \mathrm{M}$ each primer, $1 \mu \mathrm{g}$ target DNA (5 min at $94^{\circ} \mathrm{C}, 30$ cycles of: $1 \mathrm{~min} 94^{\circ} \mathrm{C}, 1 \mathrm{~min}$ $65^{\circ} \mathrm{C}-0.5^{\circ} \mathrm{C}$ per cycle, $3 \mathrm{~min}$ at $72^{\circ} \mathrm{C}, 10 \mathrm{~min}$ at $72^{\circ} \mathrm{C}$ ).

Analyses of Archaea 16S rDNA. DNA from samples that were positive for bacterial DNA were then PCR amplified using the 21F (5'-TTCCGGTTGATCCYGCCGGA-3'; DeLong 1992) and 915R (5'-GTGCTGCCCCGCCAATTCCT-3'; Stahl \& Amann 1991) Archaeaspecific primers. PCR products positive for archaeal DNA from both Bermuda and Panama were cloned into pGem Easy Vector as recommended by the manufacturer (Promega). To minimize the effect of overamplification of rare sequences in the latter cycles of PCR, $1 / 10$ dilutions of the input DNA were made. The dilution that gave a detectable signal was used in the subsequence cloning and sequencing.

Transformants were selected for on Luria-Bertani (LB)/ampicillin plates with X-gal (5-bromo-4-chloroindoly $\beta$-D-galacto-pyranoside). White colonies were picked into 96-well plates and subjected to PCR with M13F (5'-GTAAAACGACGGCCAGT-3') and M13R (5'-CAGGAAACAGCTATGAC-3') to check for inserts. The PCR products that contained inserts were cleaned using the Ultra Clean PCR Clean-Up Kit (Mo Bio) and sequenced using the $21 \mathrm{~F}$ primer.

Analysis of 16S rDNA sequences. FastGroup was used to dereplicate the libraries of $16 \mathrm{~S}$ rDNA sequences (Seguritan \& Rohwer 2001). FastGroup dereplicates $16 \mathrm{~S}$ rDNA libraries by comparing all the 
sequences in a data set to each other, grouping similar sequences together, and outputting a representative sequence from each group. For this study, ambiguous bases $(\mathrm{N})$ were removed at the $5^{\prime}$ end, sequences were trimmed to the 534 conserved site from the 3 ' end, and sequences $>97 \%$ identical were placed in the same group (Seguritan \& Rohwer 2001). Sequences containing many N's and those less than 300 bp in length were also removed by FastGroup. BLASTN (www.ncbi.nlm. nih.gov/blast/blast.cgi) was then used to characterize each sequence group. Groups identified as cloning vector sequences were removed from the data set. The identity of each sequence was also determined using ARB (www.arb-home.de/).

Richness and microbial diversity predictions. Chao1 was used to estimate the number of species (i.e. species richness) of the archaeal communities associated with Montastrea franksi, Diporia strigosa, and Porites astreoides (Chao 1984, Colwell \& Coddington 1994).

$$
S_{\text {chao1 }}=S_{\text {obs }}+n_{1}^{2} / 2 n_{2}
$$

$S_{\text {chao1 }}$ is the species richness calculated using the occurrence of singlets $\left(n_{1}\right)$ and doublets $\left(n_{2}\right)$ and the number of different groups observed in the library $\left(S_{\text {obs }}\right)$. Diversity of the microbial populations associated with these same corals was characterized using the Shannon-Wiener index ( $H^{\prime}$; Shannon \& Weaver 1949), where $P_{i}$ is the percent of the total number of sequences for 1 group.

$$
H^{\prime}=-\sum\left[P_{i}\left(\ln P_{i}\right)\right]
$$

Fluorescent in situ hybridizations (FISH) using peptide nucleic acid (PNA) probes. Coral samples preserved in $2 \%$ paraformaldehyde were airbrushed $(<2.7$ bar $)$ into a Ziploc bag with filtered autoclaved seawater (FASW). The total volume of tissue slurry was recorded for subsequent calculations of number of cells per $\mathrm{cm}^{2}$ coral surface. Tissue slurries were stored at $4^{\circ} \mathrm{C}$. One hundred $\mu \mathrm{l}$ of coral tissue slurry was diluted into $5 \mathrm{ml}$ of $0.2 \mu \mathrm{m}$ filtered phosphate buffered saline (PBS) and vacuum filtered $(<0.7$ bar) onto a $0.2 \mu \mathrm{m}$ Anodisc (Whatman) using a tower. The filters were washed with $5 \mathrm{ml}$ PBS and then treated with $2 \mathrm{ml}$ of $50 \%$ ethanol $\left(-20^{\circ} \mathrm{C}\right)$ for $5 \mathrm{~min}$. Filters were washed again with $5 \mathrm{ml}$ PBS, placed into a sterile Petri dish, then $100 \mu$ of hybridization buffer from the PNA Micro Dx FISH Reagent Kit (Applied Biosystems) containing the PNA probe (Applied Biosystems), 0.25 to $0.5 \mu \mathrm{M}$ final concentration, was pipetted onto the center of the filter. Filters were incubated in the dark for $30 \mathrm{~min}$ at $45^{\circ} \mathrm{C}$ (Archaea-specific probe: 5'-TGC TCC CCC GCC AAT TCC-3'; DeLong 1992; fluorescein labeled) or $55^{\circ} \mathrm{C}$ (EuBacteria-specific probe: 5'-CTG CCT CCC GTA GGA-3'; Perry-O'Keefe et al. 2001; Cy3 or fluo- rescein labeled). To ensure specificity of PNA probes, control hybridizations using the Halobacterium sp. and Salmonella sp. were run concurrently with the coral hybridizations. A no-probe hybridization was also run with each coral sample to compare fluorescence from the probe against the auto-fluorescent properties of the coral tissues. There was an easily discernible difference in the signal between the probe positive and no-probe hybridizations. Filters were washed 3 times at $45^{\circ} \mathrm{C}$ (Archaea) or $55^{\circ} \mathrm{C}$ (Bacteria) for $10 \mathrm{~min}$ with $5 \mathrm{ml}$ pre-warmed wash buffer from the PNA Micro Dx FISH Reagent Kit. After the washing step, the filters were dried in a $37^{\circ} \mathrm{C}$ incubator and counterstained with DAPI (4',6'-diamidino-2-phenylindole; $5 \mu \mathrm{g} \mathrm{ml}^{-1}$ ). Filters were mounted onto slides with $20 \mu \mathrm{l}$ of anti-fade solution (50\% glycerol, 50\% PBS and $0.01 \%$ ascorbic acid).

Cells were visualized using a Leica DM RBE microscope equipped for epifluorescence with a mercury bulb (50 W) and filter set XF57-1 (Omega). Images were captured using a charged coupled device (CCD) camera (Olympus America) using the DAPI filters, as well as the fluorescein or Cy3 filter set for probe specific cell counts. Cells positive for both DAPI and probe were counted in 10 to 20 fields selected at random.

Calculation of coral surface area. To determine the surface area of coral samples a standard curve of measured aluminum foil size $\left(\mathrm{mm}^{2}\right)$ and weight (mg) was constructed. Pieces of foil were cut at different sizes from 1 to $5 \mathrm{~cm}^{2}$ and weighed to determine the relationship of surface area to $g$ foil. Pieces of foil were then carefully cut to fit onto coral surface, weighed, and the surface area of coral samples was estimated by comparison to the standards.

\section{RESULTS AND DISCUSSION}

\section{Occurrence of coral-associated Archaea}

To determine if Archaea are associated with healthy corals, total DNA was harvested from 6 coral species and assayed using Archaea-specific PCR. As shown in Table 1, archaeal 16S rDNAs were found on $26 \%$ Colpophyllia natans, $100 \%$ Diploria strigosa, $39 \%$ Montastraea spp., and 62\% Porites spp. collected from Bocas del Toro, Panama (BT). Archaea were also found on $50 \%$ of Porites astreoides samples collected from Whale Bone Bay, Bermuda (BM). Archaeal 16S rDNAs were not detected on D. strigosa and $M$. franksi samples from Bermuda or on Acroporid samples from Puerto Rico. To ensure that PCR quality DNA was present all samples were PCR amplified using Bacteria-specific primer 27F and uni- 
Table 1. Detection of Archaea on corals by PCR amplification with 21F and 915R archaeal specific primers. Coral samples were collected from Whale Bone Bay, Bermuda (BM), Bocas del Toro, Panama (BT), and La Parguerra, Puerto Rico (PR)

\begin{tabular}{|c|c|c|c|c|c|}
\hline Coral species & Location & Date & $\begin{array}{l}\text { PCR positive for } \\
\text { archaeal 16S rDNA }\end{array}$ & $\begin{array}{c}\text { Total no. of } \\
\text { samples screened }\end{array}$ & $\%$ positive \\
\hline Colpophyllia natans & BT & Apr-99 & 5 & 19 & 26 \\
\hline Diploria strigosa & $\begin{array}{l}\mathrm{BM} \\
\mathrm{BT}\end{array}$ & $\begin{array}{l}\text { Aug-99 } \\
\text { Jun-00 }\end{array}$ & $\begin{array}{l}0 \\
4\end{array}$ & $\begin{array}{l}6 \\
4\end{array}$ & $\begin{array}{r}0 \\
100\end{array}$ \\
\hline Montastraea annularis & BT & Apr-99 & 2 & 3 & 67 \\
\hline Montastraea franksi & $\begin{array}{l}\text { BM } \\
\text { BT } \\
\text { BT }\end{array}$ & $\begin{array}{c}\text { Aug-99 } \\
\text { Apr-99 } \\
\text { Jun-00 }\end{array}$ & $\begin{array}{l}0 \\
0 \\
3\end{array}$ & $\begin{array}{l}5 \\
2 \\
8\end{array}$ & $\begin{array}{r}0 \\
0 \\
38\end{array}$ \\
\hline Porites astreoides & $\begin{array}{l}\mathrm{BM} \\
\mathrm{BT}\end{array}$ & $\begin{array}{c}\text { Aug-99 } \\
\text { Jun-00 }\end{array}$ & $\begin{array}{r}3 \\
15\end{array}$ & $\begin{array}{r}6 \\
24\end{array}$ & $\begin{array}{l}50 \\
63\end{array}$ \\
\hline Porites furcata & $\begin{array}{l}\mathrm{BT} \\
\mathrm{BT}\end{array}$ & $\begin{array}{l}\text { Apr-99 } \\
\text { Jun-00 }\end{array}$ & $\begin{array}{l}7 \\
3\end{array}$ & $\begin{array}{r}11 \\
5\end{array}$ & $\begin{array}{l}64 \\
60\end{array}$ \\
\hline Acropora cervicornis & $\mathrm{PR}$ & Jan-02 & 0 & 8 & 0 \\
\hline Acropora prolifera & $\mathrm{PR}$ & Jan-02 & 0 & 3 & 0 \\
\hline
\end{tabular}

versal primer 1492R. All of the samples used were positive with the Bacteria-specific PCR. This does not mean that Archaea were not present on the negative samples because our limit of detection was $\sim 10^{7}$ targets per $\mu \mathrm{l}$ of DNA.

\section{S rDNA analyses of coral-associated Archaea}

A total of 353 archaeal 16S rDNA sequences were obtained from 6 coral colonies representing 3 coral species. Using a $97 \%$ identity cut off, these sequences contained 93 archaeal ribotypes. The most abundant ribotype was observed in 58 clones. Using the Chao1 estimator (Chao 1984, Colwell \& Coddington 1994), it was calculated that this population of corals harbors 213 different species of Archaea. The ShannonWiener diversity index (Shannon \& Weaver 1949) for the community was 3.4 , indicating that archaeal communities on corals are diverse, rivaling diversity estimates of coral-associated bacterial communities (Acropora spp., $H^{\prime}=2.2$; Diploria strigosa, $H^{\prime}=4.2$; Montastraea franksi, $H^{\prime}=3.4$; Porites spp., $H^{\prime}=2.5$; taken from Rohwer et al. 2002).

The archaeal community on corals consists of species from both the Crenarchaeota and the Euryarchaeota (Fig. 1), including some species from Marine Groups I and II. In another study on coral-associated Archaea (Kellogg 2004), archaeal species from Marine Groups I, II, and III were found. Seventy-three percent of the sequences were most closely related to Crenarchaeaotes and $27 \%$ to Euryarchaeotes. The 2 most abundant sequences in the community were closely related to Crenarchaeotes (BT60MF7AA7, BT60MF7 AF7) and represented $33 \%$ of all the clones. These
2 archaeal ribotypes were found on all 3 coral species, showing that coral-associated Archaea were not species-specific. The third most abundant ribotype was a Euryarchaeote (BT60PA9AC8) present on only 1 coral sample, Porites astreoides (PA9) from Panama. The archaeal community of PA10, a P. astreoides colony located next to PA9, contained mostly Crenarchaeotes $(95 \%)$. This shows that individual coral colonies may be dominated by a particular archaeal ribotype. One archaeal ribotype (BT60PA10AD9) was found on all 3 coral types from both Panama and Bermuda collected in different years. This may be a generalist Archaea that can associate with several coral species. In a concurrent study by Kellogg (2004) another generalist coral-associated Archaea was found to make up $48 \%$ of all sequences on 3 different coral species. In contrast to zooxanthellae and Bacteria, the Archaea associated with corals appear to be nonspecific.

\section{Direct counts of Archaea and Bacteria on corals using PNA probes}

FISH with Domain-specific PNA probes was used to directly count Archaea and Bacteria on corals. Control experiments using Halobacterium sp. (Archaea) and Salmonella sp. (Bacteria) were first performed to determine hybridization conditions for these probes. As shown in Fig. 2A, the Archaea-specific probe only annealed to the Halobacterium sp., and not to the Salmonella sp. in the mixture (Fig. 2B; Salmonella sp. cells are the smaller, brighter rods in the DAPI-stained field). Similarly, the Bacteria-specific probe only bound to the Salmonella sp. cells (Fig. 2C,D). 


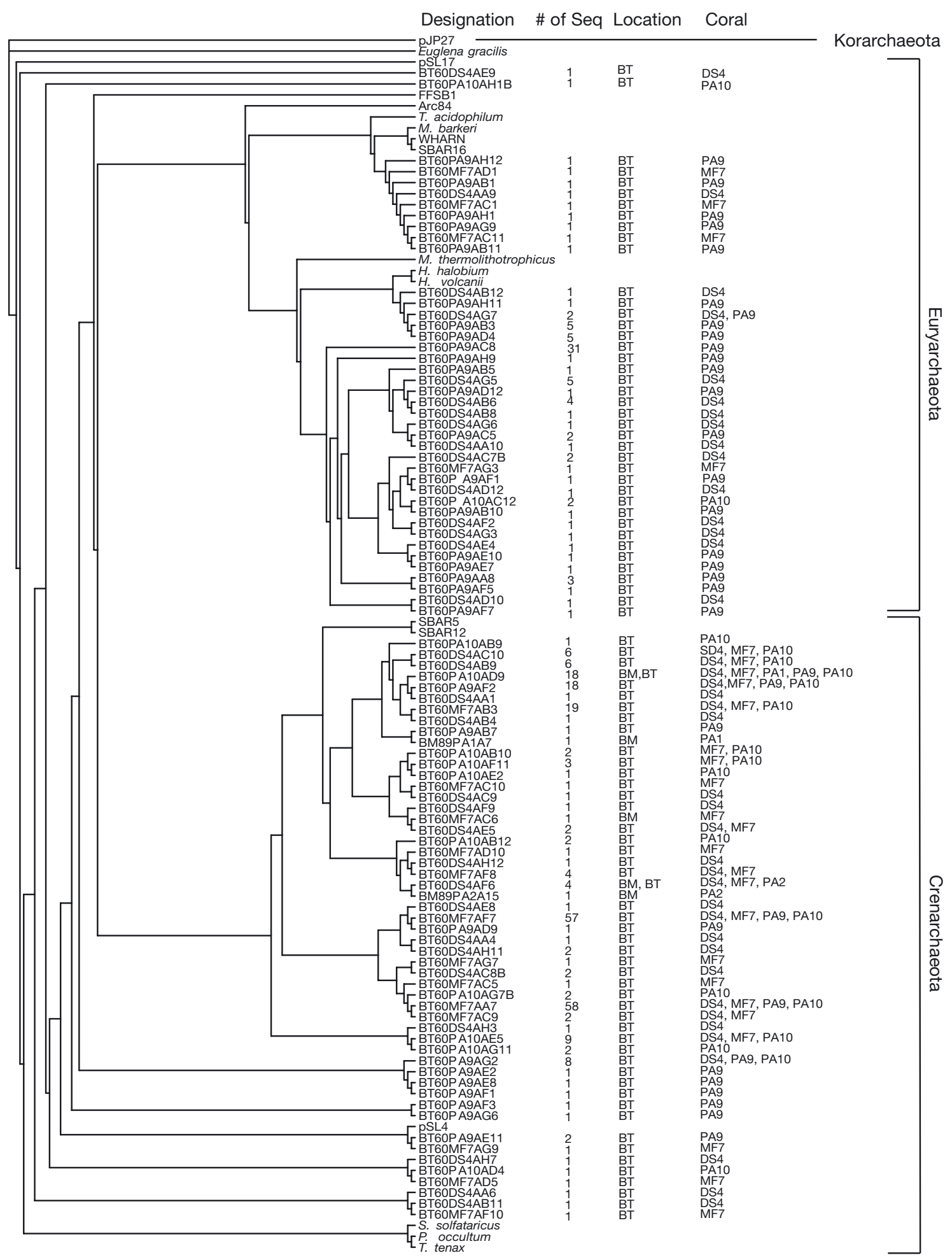

Fig. 1. Identity of archaeal groups from $16 \mathrm{~S}$ sequencing. The neighbor-joining tree was built from an ARB-alignment. Euglena gracilis was used as an outgroup. The number of clones that each sequence represented is shown (\# of Seq), as well as the location $(\mathrm{BT}=$ Bocas del Toro, Panama; $\mathrm{BM}=$ Whale Bone Bay, Bermuda), and coral species that the ribotype appeared on $(\mathrm{Coral} ;$ DS = Diploria strigosa, MF = Montastrea franksi, PA = Porites astreoides). Designation labels are coded as follows: (1) the first 2 letters represent location (BM, BT), (2) the next 2 numbers represent the month and the last digit of the year, respectively, in which the sample was collected, (3) the next 2 letters followed by a numerical digit represent coral species and colony identity, and (4) the last numbers represent the clone designation in a micro-titer plate. The sample designated on the tree is 1 representative from each group. Full names of cultured microbes and GenBank accession numbers (in parentheses) for 16S rRNA genes used as guide sequences: Halobacterium halobium NCIMB 777 (AJ002949); Haloferax volcanii (AB074566); Methanosarcina barkeri strain Fusaro (AAAR02000001); Methanococcus thermolithotrophicus (M59128); Sulfolobus solfataricus P2 (NC002754); Pyrodictium occultum (M21087); Thermoproteus tenax (AY538162); Thermoplasma acidophilum DSM 1728 (NC002578). GenBank accession numbers for uncultured 16S rRNA genes used as guide sequences: Arc84 (AY029298); FFSB1 (X96688); pJP27 (L25852); pSL4 (U63341); pSL17 (U63339); WHARN (M88078); SBAR5 (M88075); SBAR12 (M88076); SBAR16 (M88077) 

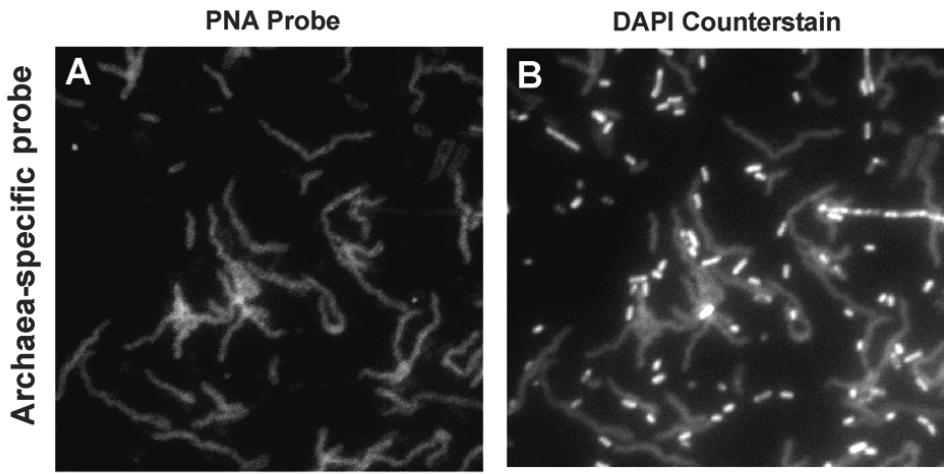

Fig. 2. Control experiments for the peptide nucleic acid (PNA) fluorescent in situ hybridizations (FISH) using Halobacterium sp. and Salmonella sp. to show that the probes were Domain specific. A mixture of Halobacterium sp. and Salmonella sp. were (A) hybridized with Archaea-specific DNA probe and (B) DAPI counterstained. On a separate filter, the same Halobacterium sp. and Salmonella sp. were (C) hybridized with a Bacteria-specific PNA probe and (D) counterstained with DAPI counter-stain. Halobacterium sp. are the long cells, while Salmonella sp. are the short rods
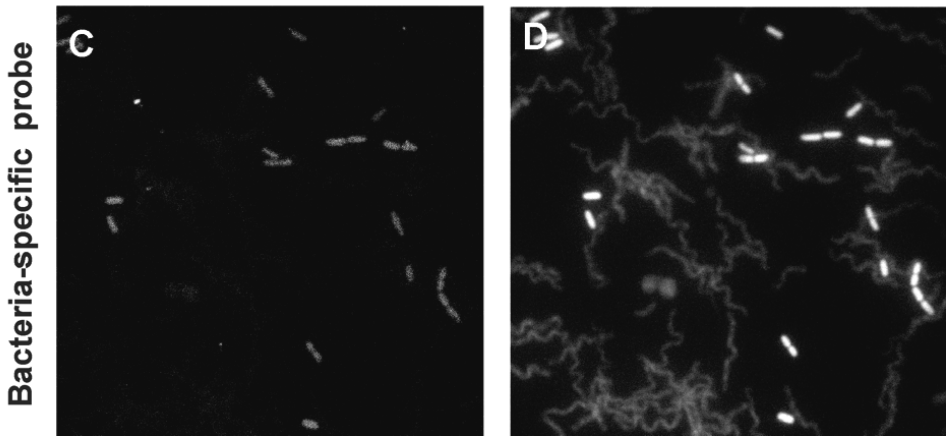

\section{CONCLUSIONS}

Archaea were commonly associated with corals, reaching concentrations of $>10^{7} \mathrm{~cm}^{-2}$. However, not all corals species (e.g. Acroporids) had detectable Archaea associates. In contrast to the coral-associated Bacteria, Archaea do not appear to form specific associations with corals. In fact, there may even be generalist Archaea associated with corals (Kellogg 2004, and present study). The coral-asso-

Cells positive for both the Archaea-specific probe and nucleic acid stain DAPI were counted as Archaea (arrows in Fig. 3). Likewise, cells positive for the Bacteria-specific probe and DAPI were counted as Bacteria. Total cell counts with a nucleic acid stain were not done because the coral lysates were extremely messy and prokaryotic cells could not be distinguished from other biological entities (e.g. mitochondria). There were an average of $8.5 \times 10^{7}$ Archaea $\mathrm{cm}^{-2}$ on Porites spp. (Table 2). More Archaea were observed on corals than Bacteria (average $4.9 \times 10^{7}$ Bacteria $\mathrm{cm}^{-2}$ ). The number of Bacteria in the samples may have been underestimated in this study because we did not use a mixture of different probes (Bythell et al. 2002). Archaea-specific PNA hybridizations were also conducted on 4 Caribbean Acropora sp. samples, but no cells were detected.

Fig. 3. Example of peptide nucleic acid (PNA) fluorescent in situ hybridizations (FISH) to count Archaea and Bacteria on Porites astreoides. The Archaea-specific PNA probe was (A) hybridized to a paraformaldehyde fixed slurry from $P$. astreoides and (B) counterstained with DAPI. The Bacteria-specific PNA probe was (C) hybridized to the same coral sample and (D) counterstained with DAPI. Cells positive for both the PNA probe and DAPI were counted. Examples of positives are indicated with arrows
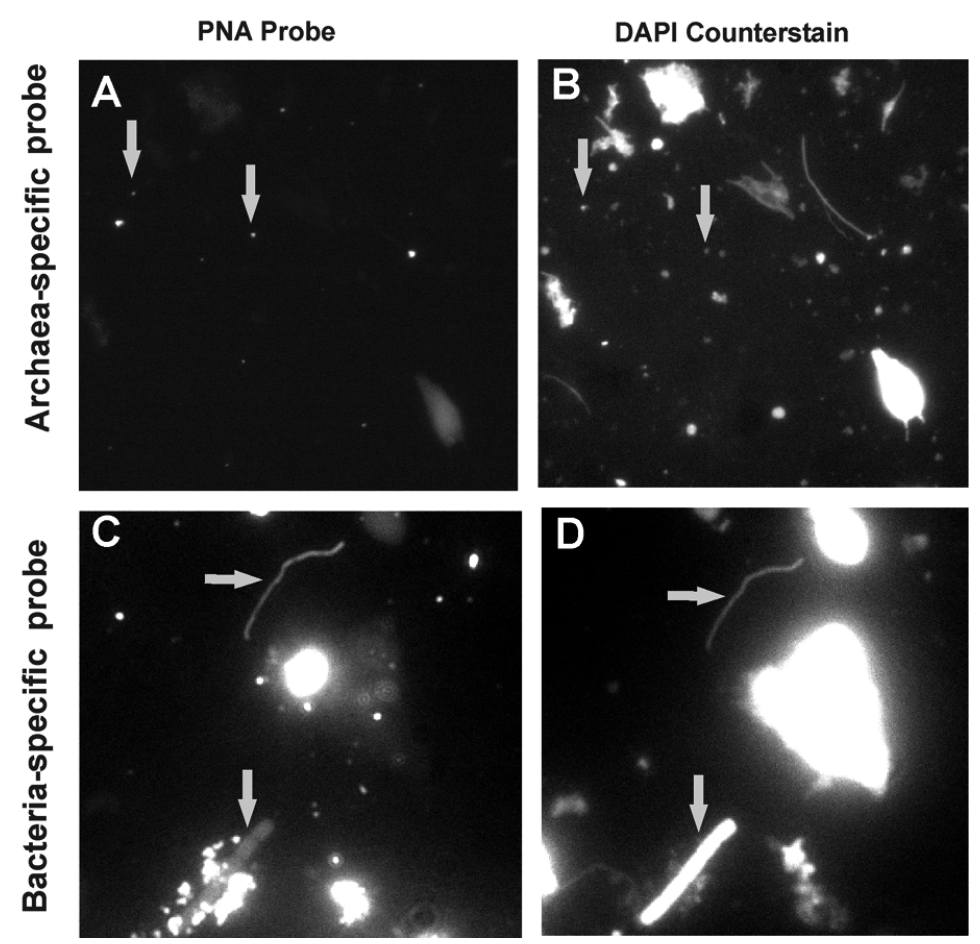
Table 2. Direct counts using fluorescent in situ hybridization (FISH) of Archaea and Bacteria on Porites spp. Both Archaea and Bacteria were present at $>10^{7} \mathrm{~cm}^{-2}$. nd = not determined

\begin{tabular}{|c|c|c|c|}
\hline Coral sample & $\begin{array}{l}\text { No. of Bacteria } \\
\mathrm{cm}^{-2}\left(\times 10^{7}\right)\end{array}$ & $\begin{array}{l}\text { No. of Archaea } \\
\mathrm{cm}^{-2}\left(\times 10^{7}\right)\end{array}$ & $\begin{array}{l}\text { Bacteria: } \\
\text { Archaea }\end{array}$ \\
\hline P. astreoides 1 & 1.5 & 1.3 & 1.17 \\
\hline P. astreoides 2 & 1.5 & 1.9 & 0.78 \\
\hline P. astreoides 3 & 1.6 & 5.1 & 0.31 \\
\hline P. astreoides 4 & 2.9 & nd & nd \\
\hline P. astreoides 5 & 3.2 & 2.8 & 1.12 \\
\hline P. astreoides 6 & 4.9 & 12 & 0.40 \\
\hline P. astreoides 7 & 7.6 & 29 & 0.26 \\
\hline P. astreoides 8 & 7.6 & 8.5 & 0.90 \\
\hline P. astreoides 9 & 11 & nd & nd \\
\hline P. astreoides 10 & 7.7 & 17 & 0.44 \\
\hline P. astreoides 11 & nd & 8.6 & nd \\
\hline P. furcata 1 & nd & 4.1 & nd \\
\hline Average & 4.9 & 8.5 & 0.67 \\
\hline
\end{tabular}

harbor organisms from all 3 Domains of life. The main challenge in future studies is to determine what role the Archaea play in the coral holobiont.

Acknowledgements. This research was supported by a grant from the National Science Foundation Biological Oceanography (OCEO1-37748). David Kline was supported by a Department of Defense NDSEG fellowship, a Smithsonian predoctoral fellowship, and a Tinker UCSD Latin American Studies Fellowship. The authors thank the Smithsonian Tropical Research Institute field station in Panama for the use of their facilities. The authors also thank the Republic of Panama (Autoridad Nacional del Ambiente, Departamento de Cuarentena Agropecuaria del Ministerio de Desarollo Agropecuaria) and the Fish and Wildlife Department of the Florida Keys for permission to collect corals. Athank you goes to the SDSU-MCF for sequencing of the 16S rDNAs and to Steve Barlow at the SDSU-EMF for help with the microscopy.

\section{LITERATURE CITED}

Amann RI, Ludwig W, Schleifer KH (1995) Phylogenetic identification and in situ detection of individual microbial cells without cultivation. Microbiol Rev 59:143-169

Baker AC, Rowan R, Knowlton N (1997) Symbiosis ecology of two Caribbean acroporid corals. Proc 8th Intl Coral Reef Symp 2:1295-1300

Bentis CJ, Kaufman L, Golubic S (2000) Endolithic fungi in reef-building corals (Order: Scleractinia) are common, cosmopolitan, and potentially pathogenic. Biol Bull (Woods Hole) 198:254-260

Brans S, Delwiche C, Palmer J, Pace N (1996) Perspectives on archaeal diversity, thermophily, and monophyly from environmental rRNA sequences. Proc Natl Acad Sci USA 93:9188-9193

Bythell J, Barer M, Cooney R, Guest J, O'Donnell A, Pantos O, Le Tissier M (2002) Histopathological methods for the investigation of microbial communities associated with disease lesions in reef corals. Let Appl Microbiol 34: 359-364
Chao A (1984) Non-parametric estimation of the number of classes in a population. Scand J Stat 11:783-791

Colwell RK, Coddington JA (1994) Estimating terrestrial biodiversity through extrapolation. Phil Trans R Soc Lond B 345:101-119

DeLong EF (1992) Archaea in coastal marine environments. Proc Natl Acad Sci USA 89:5685-5689

DeLong EF (1998) Archaeal means and extremes. Science 280:542-543

DeLong EF, Wu KY, Prézelin BB, Jovine RVM (1994) High abundance of Archaea in Antarctic marine picoplankton. Nature 371:695-697

Fuhrman J, Davis A (1997) Widespread Archaea and novel Bacteria from the deep sea as shown by 16S rRNA gene sequences. Mar Ecol Prog Ser 150:275-285

Fuhrman JA, McCallum K, Davis AA (1992) Novel major archaebacterial group from marine plankton. Nature 356: 148-149

Fuhrman JA, McCallum K, Davis AA (1993) Phylogenetic diversity of subsurface marine microbial communities from the Atlantic and Pacific oceans. Appl Environ Microbiol 59:1294-1302

Fuhrman JA, Lee SH, Masuchi Y, Davis AA, Wilcox RM (1994) Characterization of marine prokaryotic communities via DNA and RNA. Microb Ecol 28:133-146

Karner M, DeLong EF, Karl D (2001) Archaeal dominance in mesopelagic zone of the Pacific Ocean. Nature 409:507-510

Kellogg CA (2004) Tropical Archaea: diversity associated with the surface microlayer of corals. Mar Ecol Prog Ser 273:81-88

Kuhl M, Cohen Y, Dalsgaard T, Jorgenson BB, Revsbech NP (1995) Microenvironment and photosynthesis of zooxanthelle in scleractinian corals studied with microsensors for $\mathrm{O}_{2}, \mathrm{pH}$ and light. Mar Ecol Prog Ser 117:159-172

Le Campion-Alsumard T, Golubic S, Hutchins P (1995a) Microbial endoliths in the skeletons of live and dead corals: Porites lobata (Moorea, French Polynesia). Mar Ecol Prog Ser 117:149-157

Le Campion-Alsumard T, Golubic S, Priess K (1995b) Fungi in corals: symbiosis or disease? Interactions between polyps and fungi causes pearl-like skeleton biomineralization. Mar Ecol Prog Ser 117:137-147

Margot H, Acebal C, Toril E, Amilis R, Fernandez Puentes J (2001) Consistent association of crenarchaeal Archaea with sponges of the genus Axinella. Mar Biol 150: 739-745

Massana R, Murray A, Preston CM, DeLong EF (1997) Vertical distribution and phylogenetic characterization of marine planktonic Archaea in the Santa Barbara channel. Appl Environ Microbiol 63:50-56

Massana R, DeLong EF, Pedros-Alio C (2000) A few cosmopolitan phylotypes dominate planktonic archaeal assemblages in widely different oceanic provinces. Appl Environ Microbiol 66:1777-1787

Murray A, Preston CM, Massana R, Taylor L, Blakis A, Wu K, DeLong EF (1998) Seasonal and spatial variability of bacterial and archaeal assemblages in the coastal water near Anvers Island, Antarctica. Appl Environ Microbiol 64: 2585-2595

Murray A, Wu K, Moyer C, Karl D, DeLong EF (1999) Evidence for circumpolar distribution of planktonic Archaea in the Southern Ocean. Aquat Microb Ecol 18:263-273

Odum HT, Odum EP (1955) Trophic structure and productivity of a windward coral reef community on Eniwetok Atoll. Ecol Monogr 25:291-320

Perry-O'Keefe H, Rigby S, Oliveira K, Sorensen D, Stender H, Coull J, Hyldig-Nielsen J (2001) Identification of indicator 
microorganisms using a standardized PNA FISH methods. J Microbiol Methods 47:281-292

Peters EC (1984) A survey of cellular reactions to environmental stress and disease in Caribbean scleractinian corals. Helgol Meeresunters 37:113-137

Preston CM, Wu KY, Molinski TF, DeLong EF (1996) A psychrophilic crenarchaeon inhabits a marine sponge: Cenarchaeum symbiosum gen. nov., sp. nov. Proc Natl Acad Sci USA 93:6241-6246

Ritchie KB, Smith GW (1995) Preferential carbon utilization by surface bacterial communities from water mass, normal, and White-band Diseased Acropora cervicornis. Mol Mar Biol Biotech 4:345-354

Ritchie KB, Smith GW (1997) Physiological comparison of bacterial communities from various species of scleractinian corals. Proc 8th Int Coral Reef Symp 1:521-526

Rohwer F, Breitbart M, Jara J, Azam F, Knowlton N (2001) Diversity of bacteria associated with the Caribbean coral Montastraea franksi. Coral Reefs 20:85-95

Rohwer F, Seguritan V, Azam F, Knowlton N (2002) Diversity and distribution of coral-associated bacteria. Mar Ecol Prog Ser 243:1-10

Rowan R (1998) Diversity and ecology of zooxanthellae on coral reefs. J Phycol 34:407-417

Rowan R, Knowlton N (1995a) The ecological significance of genetic diversity in corals and their algal symbionts. J Cell Biochem Suppl 0:334

Rowan R, Knowlton N (1995b) Intraspecific diversity and ecological zonation in coral-algal symbiosis. Proc Natl Acad Sci USA 92:2850-2853

Rowan R, Knowlton N, Baker A, Jara J (1997) Landscape ecology of algal symbionts creates variation in episodes of coral bleaching. Nature 388:265-269

Santavy DL (1995) The diversity of microorganisms associated with marine invertebrates and their roles in the maintenance of ecosystems. In: Allsopp D, Colwell RR,

Editorial responsibility: Otto Kinne (Editor), Oldendorf/Luhe, Germany
Hawksworth DL (eds) Microbial diversity and ecosystem function. CAB International, Wallingford, p 211-229

Seguritan V, Rohwer F (2001) FastGroup: a program to dereplicate libraries of $16 \mathrm{~S}$ rDNA sequences. BMC Bioinformatics 2:9, available at: www.biomedcentral.com/14712105/2/9

Shannon CE, Weaver W (1949) The mathematical theory of communication. University of Illinois Press, Urbana, IL

Shashar N, Cohen Y, Loya Y, Sar N (1994) Nitrogen fixation (acetylene reduction) in stony corals: evidence for coralbacteria interactions. Mar Ecol Prog Ser 111:259-264

Shashar N, Banaszak AT, Lesser MP, Amrami D (1997) Coral endolithic algae: Life in a protected environment. Pac Sci 51:167-173

Smith PH, Hungate RE (1958) Isolation and characterization of Methanobacterium ruminantium n. sp. J Bacteriol 75: 713-718

Stahl DA, Amann R (1991) Development and application of nucleic acid probes. In: Stackerbrandt E, Goodfellow M (eds) Nucleic acid techniques in bacterial systematics. John Wiley \& Sons, Chichester, p 205-248

Toller WW, Rowan R, Knowlton N (2002) Genetic evidence for a protozoan (phylum Apicomplexa) associated with corals of the Montastraea annularis species complex. Coral Reefs 21:143-146

Webster N, Watts J, Hill R (2001) Detection and phylogenetic analysis of novel Crenarchaeote and Euryarchaeote 16S ribosomal RNA gene sequences from a Great Barrier Reef sponge. Mar Biotechnol 3:600-608

Williams WM, Viner AB, Broughton WJ (1987) Nitrogen fixation (acetylene reduction) associated with the living coral Acropora variabilis. Mar Biol 94:531-535

Woese C, Kandler O, Wheelis M (1990) Towards a natural system of organisms: proposal for the domains Archaea, Bacteria, and Eucarya. Proc Natl Acad Sci USA 87: 4576-4579

Submitted: October 28, 2003; Accepted: February 24, 2004 Proofs received from author(s): May 23, 2004 